\title{
Effect of Progressive Relaxation Technique on the Anxiety Level of the Psychiatric Patients before Electro Convulsive Therapy
}

\author{
Amal Sobhy Mahmoud ${ }^{1}$; Aza Abd Elbary ${ }^{2}$; Abeer Elsayed Berma ${ }^{3}$ \\ Professor of Psychiatric Nursing and Mental Health ${ }^{l}$; Master degree of Psychiatric \\ Nursing and Mental Health ${ }^{2}$; Assistant Professor of Psychiatric Nursing and Mental \\ Health $^{3}$
}

Faculty of Nursing, Port Said University

\begin{abstract}
Background: Electroconvulsive therapy is rapidly-acting treatments and one of the most effective for many psychiatric conditions as major depression, schizophrenia, and bipolar disorder. The majority of psychiatric patients describe electroconvulsive therapy as a frightening treatment and they experience high level of anxiety before receiving it or when the decision to receive it is made. Aim: Is to investigate the effect of progressive relaxation technique on the psychiatric patient's anxiety level before electroconvulsive therapy. Subjects and Method: A quasi-experimental design was used in this study that carried out at the inpatient units at Port Said Psychiatric Health Hospital. The subjects of the study compromised sixty psychiatric inpatients to whom electroconvulsive therapy were prescribed regardless of their diagnosis. They were divided into two equal groups (study and control) with thirty patients in each group. The study data were collected by using the Spielberger State Anxiety Inventory (STAI), in addition to personal and clinical data questionnaire. Results: $60.0 \%, 53.3 \%$ respectively of control and studied group had mild anxiety after progressive relaxation technique. Conclusion: The revealed that there are significant differences between controls and studied group of patients in relation to presence of someone who support patients socially and psychologically especially relatives during treatment at hospital. Most of control and studied group had mild anxiety after progressive relaxation technique. Finally, there were significant differences between before and after progressive relaxation in studied group. Recommendations: Progressive relaxation technique may be used as complementary treatment to decrease the hospitalized psychiatric patient's anxiety. The psychiatric nurse can easily apply this technique to manage patients' anxiety.
\end{abstract}

Key words: Anxiety, Electroconvulsive therapy, Relaxation techniques. 


\section{INTRODUCTION}

Electroconvulsive therapy (ECT) is used around the world for a lot of strong and management-resistant psychiatric disorders. Researches revealed that ECT is the most efficient and fast therapy form accessible to senior citizens with depression, bipolar disorder and psychosis (Kerner and Prudic, 2014). ECT can be lifesaving. For old age cases who endure or react badly to therapies with higher possibility for drug-induced toxicity, ECT is the safest therapeutic modality (Weiner, 2013). ECT is very effective even when associated with these circumstances. Throughout the next decade, researches have to focus on the usage of ECT as a synergistic medication, to improve other biological and psychological therapies, and avoid relapse manifestations (Leiknes, Jarosh-von Schweder, \& Hoie, 2012)

A relaxation procedure is any approach, process, or activity, which helps a person to relax; to reach a condition of raised calmness; or otherwise decrease levels of stress, worry, anger or pain. Relaxation procedures are usually working as one component of an extensive stress management strategy and can reduce the blood pressure, pulse, respiratory rate, and muscle tension among other health benefits (Smith \& Jonathan, 2012).

American physician Edmund Jacobson in the 1930s introduced the progressive muscle relaxation (PMR) is an anxiety-reduction procedures. The technique involves alternation between tension and relaxation in all of the body's major muscle groups (Cuncic, 2019). Progressive relaxation technique is effective in relieving the anxiety of patients in different situations. The psychiatric nurse can easily apply this technique to manage patient's anxiety and apprehension.

\section{Significance of the study}

Electro convulsive therapy might have an important function in cases who have an anxiety not responding to usual lines of treatment accompanied with severe major depression. The concern of certain psychiatrists is that while electroconvulsive therapy can manage the depressive manifestations, it may aggravate anxiety ones (American psychiatric Association, 2013). Therefore lack of education and explanation about electroconvulsive therapy can lead to severe anxiety. So, patients primarily learned the relaxation procedure in courses taught by specialized trainers is very important. 


\section{AIM OF STUDY :}

The aim of the current study was to investigate the effect of progressive relaxation technique on the psychiatric patient's anxiety level before electroconvulsive therapy.

\section{The Objectives of this study are to:}

1. Measure level of anxiety among psychiatric patients before ECT.

2. Design the training program about progressive relaxation technique on psychiatric patients before ECT.

3. Implement the training program about progressive relaxation technique on psychiatric patients before ECT.

4. Evaluate the effect of a progressive relaxation technique program on psychiatric patients before ECT.

\section{SUBJECTS AND METHOD:}

\section{Research design}

A quasi-experimental design was followed in this study.

\section{Study setting:}

The study was conducted in the inpatient units at Port Said Psychiatric Health Hospital.

\section{Study subjects:}

The study subjects comprised sixty psychiatric inpatients to whom electroconvulsive therapy were prescribed regardless of their diagnosis. They were divided into two equal groups (study and control) with thirty patients in each group.

\section{Tool of data collection:}

The study data were collected by using The Spielberger State-Trait Anxiety Inventory (STAI):

This tool was developed by Spielberger (1977) in English language and translated into Arabic language by Abd El-Khalek (1992). The State-Trait Anxiety Inventory is one of the initial tests to evaluate state and trait anxiety individually. For this study, the researcher used The State Anxiety Inventory to measure a situational anxiety and contains 20 items. Responses of patients were measured on 4 points Likert scale; ranges from "1" to "4" as: one for not anxious at all to four that reflects severe anxiety.

Scores range from 20 to 80, with greater scores correlating with greater anxiety. Low scores denote a mild form of anxiety (20-40) whereas median scores denote a moderate form of anxiety (41-60) and high scores denote a severe form of anxiety (61-80). 
In addition, the personal and clinical data questionnaire was added: Which was documented by the investigator in Arabic language following a review of the literature. It involved personal data such as the patient's age, sex, marital status, educational level, working condition, type of work, monthly income, received financial support, number of children, birth order and live with whom. As regarding clinical characteristics, these included the diagnosis, period of illness, number of preceding hospitalizations and request for treatment, history of illness, the current duration of admission to the hospital, and number of previous treatments with ECT. Additionally, questions related to feeling about hospitalization as what do you feel inside the hospital? Are you satisfied with being in the hospital?, Do you find someone to talk to or complain about your psychological distress?, Is there anyone who supports you socially and psychologically in your hospital treatment?, how often do you visit?.

\section{Pilot Study:}

Prior performing the present study, a pilot study was conducted on $10 \%$ of hospitalized patients who receiving ECT (6 patients). The pilot study was performed to ascertain clarity and applicability of the study tool, to measure the appropriate time needed for answering the questionnaire and to determine obstacles which may face throughout data collection. No modifications were done according to the results of pilot study. The pilot study sample excluded from the total study sample. The pilot study collected during the period from the first of June to end of June 2017.

\section{Method of Data Collection:}

- The researcher attended the hospital manger to introduce self, explain the purpose of the study and the sampling technique that will be followed; then, the manger referred the researcher to the responsible nurse of each unit.

- The researcher interviewed those who gave their consent. Each interview lasted for 35-45 minutes, depending on the response of the interviewee.

- The researcher started to collect data three times per week, and the process of data collection lasted for a period of one year from end of August 2017 to September2018.

- The program was implemented in six sessions; two first sessions were related to the theoretical part of the program and the last four sessions included progressive relaxation techniques. It applied in 6 sessions, one hour for every session, for 6 days. The program was presented in clear and concise form focusing on the program objectives which is the 
implementation of a progressive relaxation technique on psychiatric patients before ECT using different teaching methods such as small group discussions, demonstration, redemonstration and role playing.

\section{ADMINISTRATIVE DESIGN:}

Prior initiating any step in the study, official letters were issued from the dean of the faculty of nursing to manger of psychiatric health hospital in Port Said city requesting their cooperation and approval to perform the research, following the explanation the aim of the study.

Also, permission was obtained from the General Secretariat of Mental Health and Addiction Treatment to conduct the study at the Port Said Psychiatric Health Hospital.

\section{Ethical Considerations:}

The research proposal was approved by the pertinent committees in the Faculty of Nursing. The researcher explained the aim of the study to manger of psychiatric health hospital in Port Said City to take his permission to carry out the study.

Before starting the interview a verbal consent was taken from the patients and after a short introduction about the aim of the study in order to gain patient's cooperation. The researcher also informed them about their rights to refuse. They were ensured that any information obtained will be confidential and used only for the purpose of the study. Also, they were told that there was no right or wrong answers; it is just honest expression of their feelings and behaviors, "privacy".

\section{STATISTICAL DESIGN:}

\section{Statistical Analysis}

Data were entered into the software program (SPSS) version 20 was utilized for statically analysis and tabulation. Statistical significance and associations were used percentage, mean, standard deviation (SD), chisquare $\left(\mathrm{X}^{2}\right)$ and $\mathrm{t}$ test to detect the relations between the variables. Statistical significant difference was considered when P-Value $\leq 0.05$.

\section{RESULTS :}

The study result shows personal characteristics of the psychiatric patients. As regard age, $40.0 \%$ of the controlled group less than 30 years, and $43.3 \%$ of the studied group of patients ware in the age group ranging between 30-40 years old. Concerning 
their sex; the majority of the patient in control and studied groups of patients ware males. It is also observed that, $46.7 \%$ of the control and studied groups of patients were single. Looking to their level of education, it is found that, $43.3 \%$ in the control group had read and writes, also in the studied group $36.7 \%$ had read and writes. In relation to their patients' current employment status, $50.0 \%, 63.3 \%$ of patients were not working in the control and studied group of patients respectively.

There were insignificant differences between control and studied group of patients in relation to personal characteristics.

Regarding clinical characteristics of the studied patients there were insignificant differences between two groups, the highest percentage of them request treatment by relatives (96.7\%). Regarding diagnosis in control group 76.7\% diagnosed with schizophrenia, followed by $23.3 \%$ with bipolar disorder, while, $80.0 \%$ of the patients diagnosed with schizophrenia, $13.3 \%$ with bipolar disorder and only $6.7 \%$ with schizoeffective disorder in the studied group. Regarding onset of mental illness $30.0 \%$ in control and studied groups of patients stated that it was from less than 5 years ago. While, $33.3 \%$ in control group and $26.7 \%$ of studied groups of patients reported that it was from $5-<10$ years ago. In relation to family history, the majority of patients in control group and study had no family history $93.0 \%$ and $83.0 \%$ respectively.

In control group mean duration of starting treatment was7.94 \pm 4.69 more than of studied group $8.85 \pm 6.48$. Regarding duration of current hospitalizing, $73.3 \%$ of control group of patients and $63.3 \%$ in studied group of patients admitted for one month or more.

Table (1): revealed that there are significant differences between controls and studied group of patients in relation to presence of someone who support patients socially and psychologically especially relatives during treatment at hospital with pvalue 0.009 where in studied group $60.0 \%$ of them had social and psychiatric support more than control group.

Table (2): indicated that $50.0 \%, 53.0 \%$ of control and studied patients had a moderate level of anxiety, whereas only $10.0 \%$ had a severe level of anxiety in two groups without any significant differences P-value 1.000. 
Table (3): represents that; most of control and studied group had mild anxiety after progressive relaxation technique $(60.0 \%, 53.3 \%$ respectively) with insignificant differences p-value 0.919

Table (4): shows that there were significant differences between before and after progressive relaxation in studied group as p-value 0.021 . Regarding percent score in control group mean score was $38.50 \pm 23.17$ before and after was $31.83 \pm 21.49$ and in studied group was $39.17 \pm 20.35$ before and after was $28.44 \pm 20.77$.The results also represent that mean total score in control group was $43.10 \pm 13.90$ before and after was $39.10 \pm 12.89$ and in studied was $43.50 \pm 12.21$ before and after was $37.07 \pm 12.46$

Table (1): Distribution of patients' feelings toward hospitalization

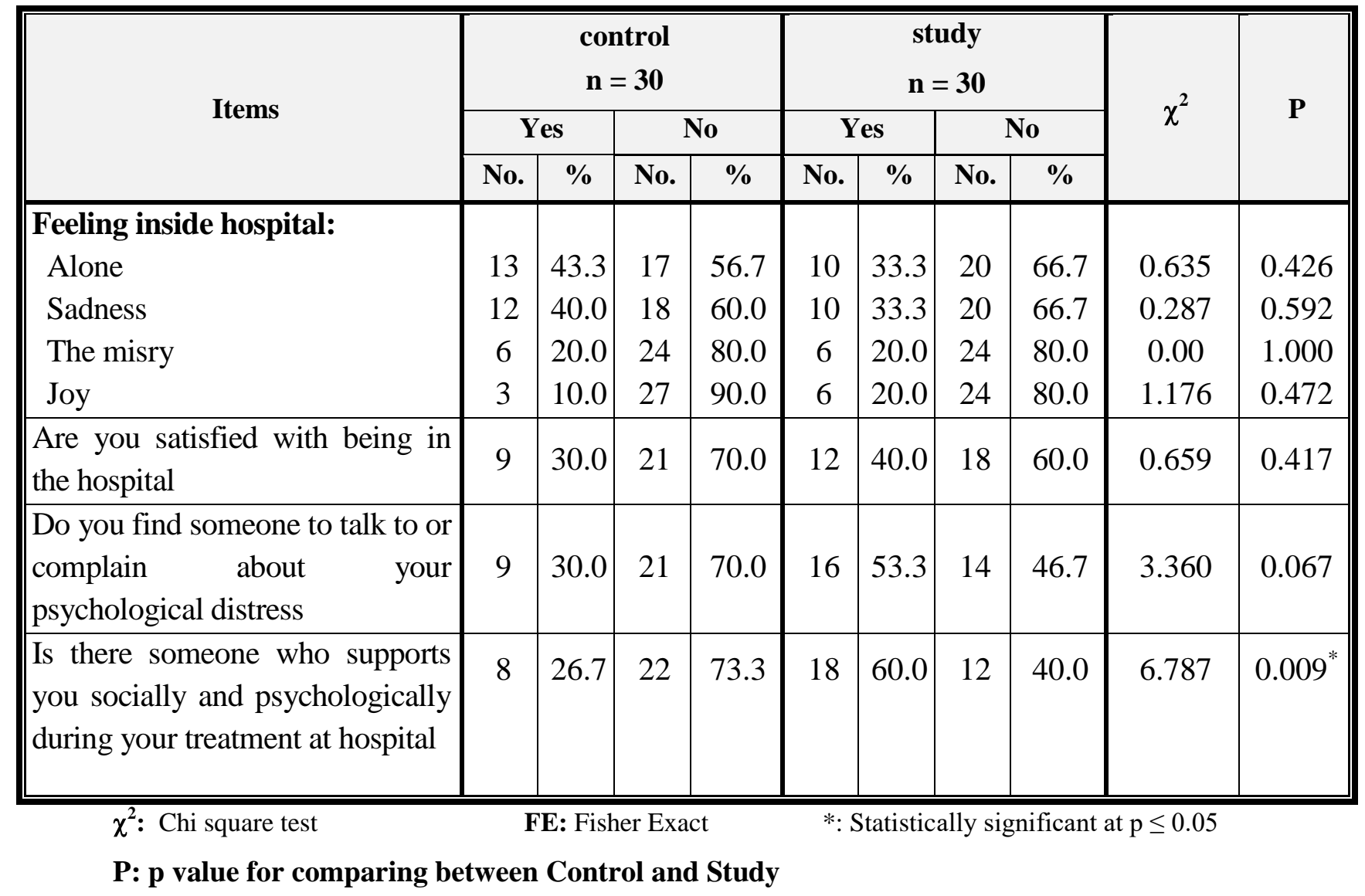


Table (2): Comparison between control and studied groups according to anxiety levels before progressive relaxation technique

\begin{tabular}{|c|c|c|c|c|c|c|}
\hline \multirow[t]{2}{*}{ Anxiety levels } & \multicolumn{2}{|c|}{$\begin{array}{c}\text { Control } \\
\text { group } \\
\mathbf{n}=\mathbf{3 0}\end{array}$} & \multicolumn{2}{|c|}{$\begin{array}{l}\text { Study } \\
\text { group } \\
\mathbf{n}=\mathbf{3 0}\end{array}$} & \multirow[t]{2}{*}{$\chi^{2}$} & \multirow[t]{2}{*}{${ }^{\mathrm{MC}} \mathbf{p}$} \\
\hline & No. & $\%$ & No. & $\%$ & & \\
\hline Mild Anxiety & 12 & 40.0 & 11 & 36.7 & \multirow{3}{*}{0.185} & \multirow{3}{*}{1.000} \\
\hline Moderate Anxiety & 15 & 50.0 & 16 & 53.3 & & \\
\hline Severe Anxiety & 3 & 10.0 & 3 & 10.0 & & \\
\hline
\end{tabular}
$\chi^{2}$ : Chi square test
MC: Monte Carlo
*: Statistically significant at $\mathrm{p} \leq 0.05$

P: $\mathrm{p}$ value for comparing between Control and Study

Table (3): Comparison between control and studied groups according to anxiety levels after progressive relaxation technique

\begin{tabular}{|c|c|c|c|c|c|c|}
\hline \multirow[t]{2}{*}{ Anxiety levels } & \multicolumn{2}{|c|}{$\begin{array}{l}\text { Control } \\
\text { group } \\
\mathbf{n}=\mathbf{3 0}\end{array}$} & \multicolumn{2}{|c|}{$\begin{array}{l}\text { Study } \\
\text { group } \\
\mathbf{n}=\mathbf{3 0}\end{array}$} & \multirow{2}{*}{$\chi^{2}$} & \multirow{2}{*}{${ }^{{ }^{M C}} \mathbf{p}$} \\
\hline & No. & $\%$ & No. & $\%$ & & \\
\hline Mild Anxiety & 18 & 60.0 & 16 & 53.3 & \multirow{3}{*}{0.441} & \multirow{3}{*}{0.919} \\
\hline Moderate Anxiety & 10 & 33.3 & 12 & 40.0 & & \\
\hline Severe Anxiety & 2 & 6.7 & 2 & 6.7 & & \\
\hline
\end{tabular}
$\chi^{2}$ : Chi square test
MC: Monte Carlo
P: $\mathrm{p}$ value for comparing between Control and Study

*: Statistically significant at $\mathrm{p} \leq 0.05$ 
Table (4): Comparison between the control and studied groups according to total and percent score before and after progressive relaxation technique

\begin{tabular}{|c|c|c|c|c|c|c|c|c|}
\hline \multirow[t]{2}{*}{ Items } & \multicolumn{3}{|c|}{$\begin{array}{l}\text { Control } \\
\mathbf{n}=\mathbf{3 0}\end{array}$} & \multicolumn{3}{|c|}{$\begin{array}{l}\text { Study } \\
\mathbf{n}=\mathbf{3 0}\end{array}$} & \multirow[t]{2}{*}{$\mathbf{p}_{2}$} & \multirow[t]{2}{*}{$\mathbf{p}_{3}$} \\
\hline & Before & After & $\mathbf{p}_{1}$ & Before & After & $\mathbf{p}_{1}$ & & \\
\hline $\begin{array}{l}\text { Total score } \\
\text { Min. - Max. } \\
\text { Mean } \pm \text { SD. }\end{array}$ & $\begin{array}{c}21.0-76.0 \\
43.10 \pm 13.90\end{array}$ & $\begin{array}{c}20.0-69.0 \\
39.10 \pm 12.89\end{array}$ & \multirow[b]{2}{*}{0.064} & $\begin{array}{c}21.0-76.0 \\
43.50 \pm 12.21\end{array}$ & $\begin{array}{c}20.0-65.0 \\
37.07 \pm 12.46\end{array}$ & \multirow[b]{2}{*}{$0.021^{*}$} & \multirow[b]{2}{*}{0.906} & \multirow[b]{2}{*}{0.537} \\
\hline $\begin{array}{l}\text { Percent score } \\
\text { Min. - Max. } \\
\text { Mean } \pm \text { SD. }\end{array}$ & $\begin{array}{c}1.67-93.33 \\
38.50 \pm 23.17\end{array}$ & $\begin{array}{c}0.0-81.67 \\
31.83 \pm 21.49\end{array}$ & & $\begin{array}{c}1.67-93.33 \\
39.17 \pm 20.35\end{array}$ & $\begin{array}{c}0.0-75.0 \\
28.44 \pm 20.77\end{array}$ & & & \\
\hline
\end{tabular}

$\mathrm{p}_{1}: \mathrm{p}$ value for Paired t-test for comparing between pre and post in Experimental group

$\mathrm{p}_{2}$ : $\mathrm{p}$ value for Paired t-test for comparing between pre and post in control group

*: Statistically significant at $\mathrm{p} \leq 0.05$

\section{DISCUSSION:}

Electroconvulsive Therapy (ECT) is a well-established, high efficient and safe management for many mental illness, involving severe treatment resistant depression, mania and catatonia. ECT can be a lifesaving therapy in absence of other therapeutic modalities owing to contraindications, different clinical parameters or where other therapies have been unsuccessful. ECT includes the application of an electric current to the brain for induction of an epileptic fit. The treatment is undertaken under a general anesthetic, with muscle relaxant to modify the convulsion (Read, Harrop, Geekie, \& Renton, 2018).

The current results revealed that there are significant changes between controls and studied group of patients in relation to presence of someone who support patients socially and psychologically especially relatives during the period of treatment at hospital. The finding might be attributed to the importance of social support and the critical component of care for psychiatric patients. Social support has to be an important component of psychiatric therapy owing to its essential role in enhancing patients' quality of life. 
However, a study carried out in Egypt, demonstrated that there most of psychiatric patients have need social support to improve quality of patient life (Mahmoud, Berma \& Gabal, 2017).

The finding of the present study denoted that half of control and studied patients had a moderate level of anxiety before progressive relaxation technique with a statistically insignificant difference between the two groups. This might be due to their lack of pertinent training program provided for psychiatric patients about progressive relaxation technique to reduce anxiety before ECT. However, the result of the present study not supported by Keykha, Mahmoodi \& Keykha (2016) who examined the effect of nursing supportive care throughout ECT on state anxiety of cases and found that the mean difference of state anxiety in study group reduced significantly in comparison with control group.

Furthermore, the study result presented the most of control and studied group had mild anxiety after progressive relaxation technique. This may be due to the greater use of relaxation training in treating anxiety problems. The importance of this relation has been demonstrated in study by Pagnini, Castelnuovo, \& Molinari (2018) who shows reliable and significant efficacy of relaxation training in decreasing anxiety. This meta-analysis extends the existing literature via facilitation of a better understanding of the variability and clinical importance of anxiety improvement after relaxation training.

According to the findings of the current study, there was statistical significantly difference between before and after progressive relaxation in studied group. This may be related to the progressive relaxation technique is the choice of relaxation therapy to reduce anxiety. This interpretation is supported by Stoppler (2017) who studied stress and insomnia can be treated with progressive muscle relaxation techniques in Melissa, who illustrated that the progressive muscle relaxation is a deep relaxation procedure which has been efficiently utilized to manage stress, anxiety and insomnia with subsequent reduction of chronic pain manifestations.

Similar to the forgoing current study results, a study in India found that anxiety related symptoms improved after the use of progressive relaxation technique among people affected with psychological disorders and it could prove as a valid treatment option for anxiety and depression related disorders (Ranjita \& Sarada 2014).

This finding is in agreement with a study done by Manzoni, Pagnini \& Castelnuovo (2008), examined anxiety level before and following relaxation training for decrease of 
anxiety both in clinical and nonclinical people and revealed that a positive clinical results after the relaxation procedures in association with anxiety.

As well as, a study in Alexandria University by Kahel (2009) about the effect of progressive relaxation technique on the psychiatric patients' anxiety level before electroconvulsive therapy and reported that majority of psychiatric patients describe ECT as a frightening treatment, and they experience high level of anxiety before receiving it or when the decision to receive it is made. This severe anxiety affects the patients' ability to cope and increases their refusal and defense against ECT, which may be expressed in the form of aggression, agitation, or withdrawal.

ECT is rapidly-acting treatments and one of the most effective for many psychiatric conditions as major depression, schizophrenia, and bipolar disorder. It involves the passage of an electric current across the head of a person undergoing general anesthesia to induce a convulsion (McMurray \& Deren, 2019).

Our finding is agreed with the above condition as the diagnosis in study group the largest number diagnosed with schizophrenia, Grover, Sahoo, Rabha \& Koirala, (2019) in their review states that ECT was initially used for the treatment of schizophrenia, but over the years with the advent of antipsychotics, its use in schizophrenia has been limited. On the other hand, Knight, Jantzi, Hirdes, \& Rabinowitz (2018) reported that overall rate of ECT use was highest in patients with a provisional diagnosis of mood disorder compared with schizophrenia/other psychotic disorder or substance-related disorder.

Finally the progressive relaxation technique is a successful relaxation method to decrease the anxiety between hospitalized patients. This relaxation therapy is simple and its practice does not need trained professional or any equipment to enhance the training. This study proved as a reliable therapeutic choice for hospitalized person with anxiety before electroconvulsive therapy in minimizing the anxiety associated manifestations and to benefit the psychosocial well-being of cases. The psychiatric nurse has an important role in preparing the patients who undergo ECT physiologically and psychologically, especially in controlling patients' anxiety. Relaxation techniques are part of the nursing interventions that the psychiatric nurse can use to manage the patients' anxiety.

\section{CONCLUSION:}

In the light of the study findings, it can be concluded that there are significant differences between controls and studied group of patients in relation to presence of someone who support patients socially and psychologically especially relatives during treatment at hospital. Most of control and studied group had mild anxiety after 
progressive relaxation technique. Finally, there were significant differences between before and after progressive relaxation in studied group.

\section{RECOMMENDATIONS:}

According to the findings of the current study, the following recommendations are suggested:

- $\quad$ Progressive relaxation technique may be used as complementary treatment to decrease the hospitalized psychiatric patient's anxiety.

- Using progressive relaxation technique to control psychiatric patients' anxiety should be started as early as possible since the first hospitalization and before the first electroconvulsive therapy.

- $\quad$ The psychiatric nurse can easily apply this technique to manage patients' anxiety.

- Encourage relatives of the patient to provide socially and psychologically supports to their patients during treatment at hospital are very important.

- Continuous training program for nurses about progressive relaxation technique to control psychiatric patients' anxiety

\section{REFERENCES:}

Abdel- Khalek, A. (1992). State- Trait- Anxiety Inventory: Arabic version Cairo. AngolaEgyptian Bookshop.

American Psychiatric Association (2013). Diagnostic and Statistical Manual of Mental Disorders (5th ed.). DSM-5, Arlington, VA: American Psychiatric Publishing.

Cuncic, A. (2109). How to Practice Progressive Muscle Relaxation, unpublished Master thesis. Psychology department at the University of Western Ontario.

Grover, S., Sahoo, S., Rabha, A., \& Koirala, R. (2019). ECT in schizophrenia: A review of the evidence. Acta neuropsychiatrica, 31(3), 115-127.

Kahel, M, (2009). About the effect of progressive relaxation technique on the psychiatric patients' anxiety level before electroconvulsive therapy, unpublished Master of Nursing Sciences. The Graduate Faculty and the College of Tishreen University. 
Kerner, N., \& Prudic, J. (2014). Current electroconvulsive therapy practice and research in the geriatric population; Neuropsychiatry;4(1): 33-54. doi: 10.2217/npy.14.3.

Keykha, R., Mahmoodi, N., \& Keykha, M. (2016). Effect of nursing supportive care on state anxiety of patients receiving ECT: A controlled Randomized clinical trial. International Journal of Pharmaceutical Research and Allied Sciences, 5(3), 407412.

Knight, J., Jantzi, M., Hirdes, J., \& Rabinowitz, T. (2018). Predictors of Electroconvulsive Therapy Use in a Large Inpatient Psychiatry Population. The Journal of ECT, 34(1), 35-39.

Leiknes, K.A., Jarosh-von Schweder, L., \& Hoie, B. (2012). Contemporary use and practice of electroconvulsive therapy worldwide. Brain Behav., 2 (3), 283

Mahmoud, A., Berma, A., \& Gabal, S. (2017). Relationship between Social Support and the Quality of Life among Psychiatric Patients. Journal of Psychiatry and Psychiatric Disorders, 1(2), 57-75

Manzoni, G.M., Pagnini, F., \& Castelnuovo, G. (2008). Relaxation training for anxiety: A ten years systematic review with meta-analysis. BMC Psychiatry, 8 (41). doi:10.1186/1471-244X-8-41

McMurray, L, \& Deren, B, (2019). Efficacy of electroconvulsive therapy in bipolar versus unipolar major depression: A meta-analysis. Bipolar Disorders, 14 (2), 146-150. doi:10.1111/j.1399-5618.2012.00997.x. PMID 22420590.

Pagnini, F., Castelnuovo, G., \& Molinari, E., (2018). Relaxation training for anxiety: A ten-year systematic review with meta-analysis. BMC Psychiatry, 8(1) 24-36. doi:10.1186/1471-244X-8-41.

Ranjita, L., \& Sarada, N. (2014). Progressive Muscle Relaxation therapy in Anxiety: A Neurophysiological Study. IOSR Journal of Dental and Medical Sciences, 13 (2), 25-28.

Read, J., Harrop, A., Geekie, S., \& Renton, P. (2018). An audit of ECT in England 20112015: Usage, demographics, and adherence to guidelines and 
legislation. Psychology and Psychotherapy: Theory, Research and Practice, 91 (3), 263-277.

Smith, J. (2012). The Psychology of Relaxation. Principles and Practice of Stress Management (3rd ed.). Wilson College, Columbia.

Weiner, R. \& Prudic, J. (2013). Electroconvulsive therapy in the United States: How often is it used? Biol Psychiatry, 15(2):105-106. doi: 10.1016/j.biopsych. 


\section{تأثير تقنيات الآسترخاء التدريجى على مستوى قلى المرضى النفسيين قبل العلاج بالجلسة}

\section{الكهربائية}

\section{أمل صبحى محمود1 ، عزه عبد البارى²، عبير السيد برمهة3}

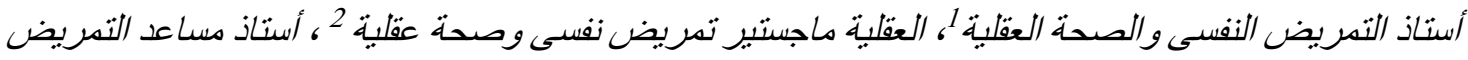

$$
\text { النفسى والصحة } 3
$$

كلية التمريض جامعة بورسعيد

\section{الخلاصة}

العلاج بالصدمة الكهربائية هو علاج سريع المفعول وواحد من أكثر الحالات فعالية للعديد من الحالات النفسية مثل الاكتئاب الثديد و الفصام و اضطر اب ثنائي القطب. غالبية المرضى النفسيين يصفون العلاج بالصدمة الكهربائية بأنه علاج مخيف ويعانون من مستوى عال من القلق قبل تلقيه أو عند اتخاذ قرار بتلقيه هذا العلاج. الهدف: هو البحث في بهي تأثثر تقنية الاسترخاء التدريجي على مستوى قلق المريض النفسي قبل العلاج الكهربائي. الأدوات وطرق البحث: تم استخدام تصميم شبه تجريبي في هذه الدر اسة التي أجريت في أقسام المرضى الداخليين في مستشفى بورسعيد للصحة النفسية. عدد عينة الدراسة ستين مريضًا نفسيًا تم وصف العلاج بالصدمات الكهربائية لهم بغض النظر عن فئرئ تتخيصهم. تم تقسيمهم إلى مجموعتين منساويتين (مجموعة للار اسة ومجموعة حاكمة) ثلاثين مريضا في كل مجموعة. تم جمع بيانات الدراسة باستخدام قائمة سبيلرجيرلقياس حالة القلق (STAI)، بالإضافة إلى استبيان البيانات الثخصية و السريرية. النتائج: 60.0٪ ، 53.3٪ على التوالي من المجموعة الحاكمة ومجموعة الدراسة يعانو المن قلق خفيف بعد تقنية الاسترخاء التدريجي. الخلاصة: كثفت أن هنالك فروق ذات دلالة إحصائية بين

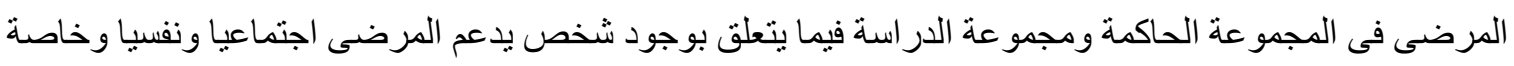
الأقارب أثناء العلاج في المستشفى. كان لمعظم مجموعة الدراسة قلقًا خفيفًا بعد تقنية الاسترخاء التدريجي. وأخيرا ، كانت هناك اختلافات كبيرة بين قبل وبعد الاسترخاء التدريجي في مجموعة الدر اسة. التوصيات: يمكن استخدام تقنية الاسترخاء التدريجي كعلاج تكميلي لتقليل قلق المريض النفسي في المستشفى. يمكن للممرضة النفسية تطبيق هذه التقنية بسهولة لمعالجة قلق المرضى. 